Tropical Journal of Pharmaceutical Research June 2021; 20 (6): 1273-1278

ISSN: $1596-5996$ (print); 1596-9827 (electronic)

(C) Pharmacotherapy Group, Faculty of Pharmacy, University of Benin, Benin City, 300001 Nigeria.

\title{
Effect of a combination of low-dose aminophylline and budesonide on lung function, serum inflammatory factors and quality of life of patients with chronic obstructive pulmonary disease
}

\author{
Shuli Zhang ${ }^{1}$, Qingfeng Liü ${ }^{2}$, Zhaojun $\mathrm{Chu}^{3}$, Lili Wang ${ }^{4}$, Fangchao Jiang ${ }^{5 *}$ \\ ${ }^{1}$ Department of Pharmacy, Jiaozhou Central Hospital of Qingdao, ${ }^{2}$ Department of Internal Medicine, Shandong Qingdao \\ Integrated Traditional Chinese and Western Medicine Hospital, Shandong Province, ${ }^{3}$ Department of Respiratory and Critical \\ Care Medicine, Zaozhuang Hospital, Zaozhuang Mining Group, ${ }^{4}$ Department of Respiratory Medicine, Shandong Qingdao \\ Integrated Traditional Chinese and Western Medicine Hospital, ${ }^{5}$ Department of General Practice, Qingdao Hospital of \\ Traditional Chinese Medicine, Qingdao Hiser Hospital, Shandong Province, China
}

*For correspondence: Email: gansichiaomhz@163.com; Tel: +86-18560609616

Sent for review: 23 March 2021

Revised accepted: 26 May 2021

\begin{abstract}
Purpose: To investigate the effect of a combination of low-dose aminophylline and budesonide on lung function, serum inflammatory factors and quality of life of patients with chronic obstructive pulmonary disease (COPD).

Methods: A total of 120 COPD patients admitted to Jiaozhou Central Hospital of Qingdao from January 2018 to January 2019 were the subjects for this study. They were divided into two groups based on the order of admission, with 60 patients in each group. The two groups of patients were treated with conventional COPD therapy. In addition, patients in group $B$ were treated with budesonide, while those in group $A$ were treated with a combination of low-dose aminophylline and budesonide. Lung function indices, serum levels of inflammatory factors, quality of life (QOL), 6-min walking distance (6MWD), and overall treatment effectiveness in the two groups were compared.

Results: Lung function indices were significantly higher in group $A$ than in group $B$, while patients in group $A$ had significantly lower serum levels of inflammatory factors than patients in group $B$ ( $p<$ 0.001). There was markedly higher $Q O L$ in group $A$ patients than in patients of group $B$, but patients in group $A$ achieved longer $6 M W D$ than group $B$ patients $(p<0.001)$. More patients showed treatment effectiveness in group $A$ than in group $B(p<0.05)$.

Conclusion: Treatment with a combination of low-dose aminophylline and budesonide effectively improves lung function indices in COPD patients, reduces serum levels of inflammatory factors, but enhances their QOL. Thus, the combination treatment may be clinically beneficial to COPD patients.
\end{abstract}

Keywords: Aminophylline, Budesonide, Chronic obstructive pulmonary disease (COPD), Lung function

This is an Open Access article that uses a fund-ing model which does not charge readers or their institutions for access and distributed under the terms of the Creative Commons Attribution License (http://creativecommons.org/licenses/by/4.0) and the Budapest Open Access Initiative (http://www.budapestopenaccessinitiative.org/read), which permit unrestricted use, distribution, and reproduction in any medium, provided the original work is properly credited.

Tropical Journal of Pharmaceutical Research is indexed by Science Citation Index (SciSearch), Scopus, International Pharmaceutical Abstract, Chemical Abstracts, Embase, Index Copernicus, EBSCO, African Index Medicus, JournalSeek, Journal Citation Reports/Science Edition, Directory of Open Access Journals (DOAJ), African Journal Online, Bioline International, Open-J-Gate and Pharmacy Abstracts

\section{INTRODUCTION}

Chronic obstructive pulmonary disease (COPD) is seen frequently in clinics. Glucocorticoid therapy is often used in clinical practice to optimize lung function indices in COPD patients so as to reduce the likelihood of deterioration of their conditions. However, the effects of 
glucocorticoids last only for a short duration, and their anti-inflammatory effects are unsatisfactory. Therefore, glucocorticoids are used in combination with other drugs so as to improve the treatment outcome of COPD patients [1-3].

It is stated in COPD treatment guidelines that bronchodilators are effective in relieving COPD symptoms, and their combination with glucocorticoids decreases inflammatory reactions in patients, thereby further enhancing their lung function. Moreover, the combined treatment has been reported to be more beneficial for long-term therapy of patients than the use of a single drug [4-7]. One of the bronchodilators used in the combined-drug treatment of COPD patients is aminophylline. This study was carried out to investigate the clinical efficacy of a combination of low-dose aminophylline and budesonide in COPD patients.

\section{METHODS}

\section{Profile of patients}

A total of 120 COPD patients admitted to our hospital from January 2018 to January 2019 were selected as the study subjects. They were assigned to two groups: $A$ and $B$, according to the order of admission. As shown in Table 1, there were no significant differences in general data between patients in the two groups ( $p>$ 0.05). This study was approved by the Institutional Review Board of Jiaozhou Central Hospital of Qingdao (approval no.: JCHQ2017965). This study was performed in accordance with the institutional guidelines of Jiaozhou Central Hospital of Qingdao.

\section{Inclusion/exclusion criteria}

\section{Inclusion criteria}

The following categories of patients were included in this study: (a) patients who signed informed consent to participate in the study, fully aware of the processes involved, or patients for whom family members signed informed consent; (b) patients whose COPD status was diagnosed and confirmed in accordance with the diagnostic criteria for COPD, and (c) patients with negative bronchodilator test results.

\section{Exclusion criteria}

Patients in the following categories were excluded from the study: (a) patients who had other organ diseases, including respiratory diseases; (b) patients who had mental health problems, or who were unable to communicate; (c) patients who had received or were receiving glucocorticoid treatments; (4) patients who had medication contraindications, and (c) pregnant or lactating patients.

\section{Treatments}

All patients were administered conventional treatments such as expectorant and oxygen inhalation. Patients in group $B$ were treated with $200 \mu \mathrm{g}$ of budesonide (AstraZeneca AB, H20140458) and 1 inhalation twice daily, while patients in group A were orally administered aminophylline (Shanxi Taiyuan Pharmaceutical Co. Ltd, GYZZ H14020283) at a low dose of 100 $\mathrm{mg}$ b.i.d. after addition of budesonide [8-11]. The treatments lasted 24 weeks for all patients.

Table 1: Baseline patient information

\begin{tabular}{lcccc}
\hline Group & Group A (n=60) & Group B (n=60) & X2/t & P-value \\
\hline Gender & 41 & 40 & 0.038 & 0.845 \\
Male & 19 & 20 & & \\
Female & $67.10 \pm 10.11$ & $67.21 \pm 11.20$ & 0.056 & 0.955 \\
Age (years) & $9.11 \pm 5.21$ & $9.20 \pm 5.41$ & 0.093 & 0.926 \\
COPD disease Course & & & & \\
(years) & & & & \\
Clinical symptoms & 55 & 56 & 0.120 & 0.729 \\
Chest distress & 35 & 34 & 0.034 & 0.853 \\
Cough & 32 & 33 & 0.034 & 0.855 \\
Breathe difficulty & & & 0.036 & 0.850 \\
Lung function & 38 & 37 & & \\
II & 22 & 23 & & \\
III & 24 & 25 & 0.035 & 0.853 \\
History of smoking & 27 & 26 & 0.034 & 0.854 \\
History of drinking & & & & \\
\hline
\end{tabular}




\author{
Determination of COPD parameters in \\ patients
}

The lung function indices measured included forced respiratory volume in 1 second (FEV1), forced vital capacity ratio (FEV1/FVC), and FEV1 as percentage of predicted value (FEV1 \%). Other parameters were serum levels of inflammatory factors, i.e., C-reactive protein (CRP), adiponectin (APN), interleukin-6 (IL-6) and QOL. For QOL, two scores for respiratory symptoms and activity limitation in St. George's Respiratory Questionnaire (SGRQ) were selected as rationale for the evaluation of $\mathrm{QOL}$ for patients in this study [12-15]. The scores ranged from 0 to 100 , with higher scores signifying lower QOL. The other lung function used was 6MWD: the 6MWD before and after treatment were compared between the two groups. The overall treatment efficacy was rated as follows: if all the symptoms of COPD disappeared, the treatment outcome was classified as significantly effective. If the symptoms of COPD were significantly reduced, the outcome was deemed effective. However, if the condition of the patient remained unchanged or became worse, the treatment outcome was classified as ineffective.

\section{Statistical analysis}

The data processing software used in this study was SPSS 20.0, while GraphPad Prism 7 (GraphPad Software, SanDiego, USA) was used for drawing pictures. Measurement data are presented as mean \pm standard deviation (SD). Enumeration data are expressed as number (\%). Chi squared $\left(\mathrm{X}^{2}\right)$ test and $t$-test were used for statistical analysis. $P<0.05$ was considered indicative of statistically significant difference.

\section{RESULTS}

\section{Lung function indices}

After treatment, lung function indices were markedly higher in group A patients than in group B patients $(p<0.001$, as shown in Table 2 .

\section{Serum levels of inflammatory factors}

As shown in Table 3, after treatment, patients in group $A$ had significantly lower serum levels of inflammatory factors than those in group $\mathrm{B}(p<$ 0.001).

\section{Quality of life (QOL)}

The SGRQ score was much lower in group $A$ patients, but group A patients had markedly higher QOL than group B patients $(p<0.001$; Figure 1).

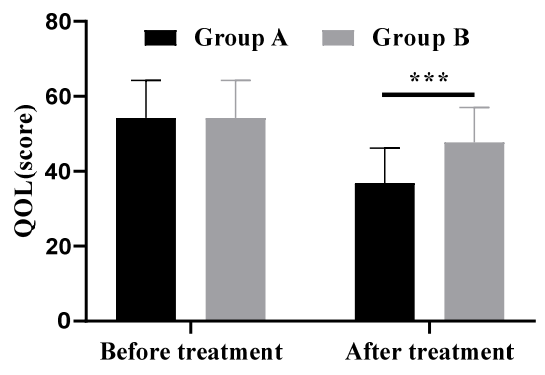

Figure 1: Comparison of QOL between the two groups of patients before and after treatment; ${ }^{*} p<$ 0.001

Table 2: Comparison of lung function indices of patients (mean \pm SD)

\begin{tabular}{|c|c|c|c|c|c|c|}
\hline Parameter & Group A & & Group B & & $t$ & $P$-value \\
\hline FEV1 & $\begin{array}{l}\text { Before } \\
\text { treatment }\end{array}$ & $1.12 \pm 0.20$ & $\begin{array}{l}\text { Before } \\
\text { treatment }\end{array}$ & $1.11 \pm 0.21$ & 0.267 & 0.790 \\
\hline \multirow[t]{3}{*}{ (L) } & After treatment & $1.80 \pm 0.41$ & $\begin{array}{l}\text { After } \\
\text { treatment }\end{array}$ & $1.42 \pm 0.35$ & 5.460 & 0.000 \\
\hline & $\mathrm{T}$ & 11.546 & $T$ & 5.883 & & \\
\hline & $P$-value & 0.000 & $P$-value & 0.000 & & \\
\hline FEV1 / FVC & $\begin{array}{l}\text { Before } \\
\text { treatment }\end{array}$ & $49.50 \pm 4.11$ & $\begin{array}{l}\text { Before } \\
\text { treatment }\end{array}$ & $49.51 \pm 4.10$ & 0.013 & 0.989 \\
\hline \multirow[t]{3}{*}{ (\%) } & After treatment & $64.10 \pm 5.11$ & $\begin{array}{l}\text { After } \\
\text { treatment }\end{array}$ & $55.40 \pm 4.15$ & 10.237 & 0.000 \\
\hline & $\mathrm{T}$ & 17.245 & $\mathrm{~T}$ & 7.821 & & \\
\hline & $P$-value & 0.000 & $P$-value & 0.000 & & \\
\hline \multirow[t]{4}{*}{ FEV1\% } & $\begin{array}{l}\text { Before } \\
\text { treatment }\end{array}$ & $51.10 \pm 4.20$ & $\begin{array}{l}\text { Before } \\
\text { treatment }\end{array}$ & $51.12 \pm 4.32$ & 0.026 & 0.980 \\
\hline & After treatment & $78.21 \pm 3.52$ & $\begin{array}{l}\text { After } \\
\text { treatment }\end{array}$ & $65.20 \pm 4.21$ & 18.364 & 0.000 \\
\hline & $\mathrm{T}$ & 38.320 & $T$ & 18.080 & & \\
\hline & $P$-value & 0.000 & $P$-value & 0.000 & & \\
\hline
\end{tabular}


Table 3: Comparison of serum inflammatory factor levels in patients $(\bar{x} \pm s)$

\begin{tabular}{|c|c|c|c|c|c|c|}
\hline Item & Group A & & Group B & & $t$ & $P$-value \\
\hline IL-6 & $\begin{array}{l}\text { Before } \\
\text { treatment }\end{array}$ & $6.31 \pm 1.05$ & $\begin{array}{l}\text { Before } \\
\text { treatment }\end{array}$ & $6.30 \pm 1.20$ & 0.049 & 0.961 \\
\hline \multirow[t]{3}{*}{ (ng/L) } & $\begin{array}{l}\text { After } \\
\text { treatment }\end{array}$ & $4.11 \pm 1.10$ & $\begin{array}{l}\text { After } \\
\text { treatment }\end{array}$ & $5.10 \pm 1.05$ & 5.043 & 0.000 \\
\hline & $\mathrm{t}$ & 11.206 & $t$ & 5.829 & & \\
\hline & $P$-value & 0.000 & $P$-value & 0.000 & & \\
\hline CRP & $\begin{array}{l}\text { Before } \\
\text { treatment }\end{array}$ & $6.94 \pm 0.95$ & $\begin{array}{l}\text { Before } \\
\text { treatment }\end{array}$ & $6.93 \pm 0.56$ & 0.070 & 0.944 \\
\hline \multirow[t]{3}{*}{ (mg/L) } & $\begin{array}{l}\text { After } \\
\text { treatment }\end{array}$ & $3.55 \pm 0.80$ & $\begin{array}{l}\text { After } \\
\text { treatment }\end{array}$ & $4.45 \pm 0.65$ & 6.763 & 0.000 \\
\hline & $\mathrm{t}$ & 21.143 & $t$ & 22.390 & & \\
\hline & $P$-value & 0.000 & $P$-value & 0.000 & & \\
\hline APN & $\begin{array}{l}\text { Before } \\
\text { treatment }\end{array}$ & $9.81 \pm 0.52$ & $\begin{array}{l}\text { Before } \\
\text { treatment }\end{array}$ & $9.80 \pm 0.54$ & 0.103 & 0.918 \\
\hline \multirow[t]{3}{*}{ (mg/L) } & $\begin{array}{l}\text { After } \\
\text { treatment }\end{array}$ & $7.80 \pm 1.11$ & $\begin{array}{l}\text { After } \\
\text { treatment }\end{array}$ & $8.52 \pm 1.02$ & 3.700 & 0.000 \\
\hline & $\mathrm{t}$ & 12.702 & $\mathrm{t}$ & 8.591 & & \\
\hline & $P$-value & 0.000 & $P$-value & 0.000 & & \\
\hline
\end{tabular}

Table 4: Comparison of overall efficacy between the two groups (n, \%)

\begin{tabular}{lcccc}
\hline Variable & Markedly effective & Effective & Invalid & Overall efficacy \\
\hline Group A & 21 & 37 & 2 & $58(96.67)$ \\
Group B & 12 & 38 & 10 & $50(83.33)$ \\
$X^{2}$ & & & & 5.926 \\
$P$-value & & & & 0.015 \\
\hline
\end{tabular}

\section{MWD values for the patients}

As shown in Figure 2, after treatment, patients in group $A$ had significantly longer 6MWD than those in group $\mathrm{B}(p<0.001)$.

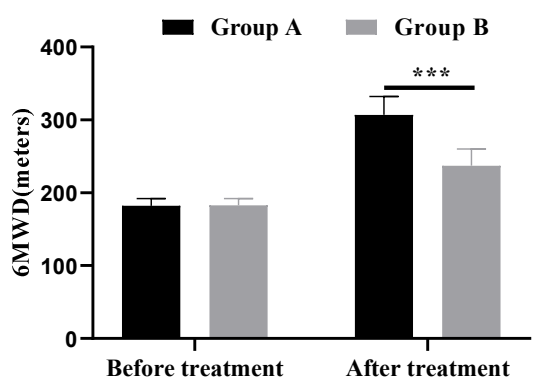

Figure 2: Comparison of 6MWD between the two groups of patients before and after treatment; ${ }^{* * *} \mathrm{P}<$ 0.001

\section{Overall treatment efficacy}

Higher number of patients presented with overall treatment effectiveness in group $A$ than in group $B\left(X^{2}=5.926, p=0.015\right)$, as shown in Table 4 .

\section{DISCUSSION}

At present, the pathogenesis of COPD has not been fully elucidated. However, it is thought that physiological and environmental factors are involved in the development of the disease. In clinical practice, COPD patients are treated using strategies that reduce airway inflammation and mitigate obstruction of airflow, so as to optimize pulmonary function. These treatments rely mostly on glucocorticoids. However, recent studies have shown that the anti-inflammatory effect of glucocorticoid monotherapy is too unsatisfactory to reduce the levels of inflammation in COPD patients: other drugs are needed as adjunctive therapy [16-19].

Aminophylline is a third-line drug used in the treatment of COPD. In this study, low-dose aminophylline was administered in combination with budesonide to patients in group $A$. Furthermore, after treatment, FEV1 was $1.80 \pm$ $0.41 \mathrm{~L} ; \mathrm{FEV} 1 / \mathrm{FVC}$ was $64.10 \pm 5.11 \%$ and FEV1 $\%$ was $78.21 \pm 3.52$ in group $A$. Lung function indices were markedly higher in group $A$ than in group B. Moreover, patients in group A had significantly lower serum levels of inflammatory factors than those in group B. Thus, aminophylline effectively increased the levels of intracellular cyclic adenosine monophosphate in patients, allowing its anti-inflammatory effect to be exerted while reducing bronchial hypersensitivity, thereby decreasing clinical symptoms of COPD.

In a study that classified COPD patients treated with combination of low-dose aminophylline and budesonide as study group, and those treated 
with budesonide alone as control group, it was found that FEV1 and FEV1/FVC of patients in the study group were $1.85 \pm 0.39 \mathrm{~L}$ and $64.50 \pm 5.02$ $\%$, respectively, post-treatment, whereas FEV1 and FEV1/FVC of patients in the control group were $1.40 \pm 0.35 \mathrm{~L}$ and $54.99 \pm 4.15 \%$, respectively. Moreover, lung function indices were markedly higher in the study group than in the control group. It has been shown that combination of low-dose aminophylline and budesonide was effective in improving pulmonary function of COPD patients [20]. Similar results were obtained in the present study.

Reduced exercise tolerance is one of the most distinct features of COPD patients. In this study, after treatment, patients in group $A$ had markedly longer 6MWD than those in group $\mathrm{B}$, indicating that aminophylline effectively enhanced their skeletal muscular activity, improved contractility of their heart muscles, and raised their capacity for exercise. In light of treatment outcomes such as significant improvement in pulmonary function and substantial increase in capacity for physical exercise, group A patients showed markedly higher QOL than those in group $\mathrm{B}$, suggesting a better overall QOL.

\section{Limitations of the study}

Despite the positive results this study yielded, it still has several limitations with respect to the interpretation of the results. First, the sample size was small, only 120 patients were included; Second, the follow-up time was short; Third, no blind method was used. Multi-center, doubleblind, large-sample clinical research is needed to further verify the conclusions of this study.

\section{CONCLUSION}

Given the above findings, we recommend lowdose aminophylline combined with budesonide a promising option for COPD patients. It is assumed that aminophylline can enhance the anti-inflammatory effect of glucocorticoids and significantly reduce serum inflammatory factor levels, providing new ideas for the treatment of COPD patients. In the meantime, whether other drugs that reduce inflammatory factors can also play a role in the treatment of COPD remains to be determined in future research.

\section{DECLARATIONS}

\section{Conflict of interest}

No conflict of interest is associated with this work.

\section{Contribution of authors}

We declare that this work was done by the authors named in this article and all liabilities pertaining to claims relating to the content of this article will be borne by the authors. Shuli Zhang, Qingfeng Liu and Zhaojun Chu conducted the experiments and collected the data; Shuli Zhang, Lili Wang, Qingfeng Liu designed the experiments and wrote the paper. Shuli Zhang and Fangchao Jiang analyzed the data. All authors reviewed and approved the final version of the manuscript for publication.

\section{Open Access}

This is an Open Access article that uses a funding model which does not charge readers or their institutions for access and distributed under the terms of the Creative Commons Attribution License (http://creativecommons.org/licenses/by/ 4.0) and the Budapest Open Access Initiative (http://www.budapestopenaccessinitiative.org/rea d), which permit unrestricted use, distribution, and reproduction in any medium, provided the original work is properly credited.

\section{REFERENCES}

1. Mostafavi-Pour-Manshadi SM, Naderi N, Barrecheguren $M$, Dehghan $A$, Bourbeau J. Investigating fractional exhaled nitric oxide (FeNO) in chronic obstructive pulmonary disease (COPD) and asthma-COPD overlap (ACO): a scoping review protocol. BMJ Open 2017; 7(12): e018954.

2. Suissa S, Sotgiu G, Brusasco V. Observational Studies in COPD: Summary of Guidance for Authors. COPD 2018; 15(5): 415-417.

3. Karlsson SL, Backer V, Godtfredsen N. A single administration of glucocorticoid increases exercise capacity in men with stable chronic obstructive pulmonary disease. Dan Med J 2019; 66(1): A5522.

4. Duffy SP, Criner GJ. Chronic Obstructive Pulmonary Disease: Evaluation and Management. Med Clin North Am 2019; 103(3): 453-461.

5. Oshagbemi OA, Burden AM, Shudofsky KN, Driessen JHM, Vestergaard $P$, Krings A, Franssen FME, van den Bergh $J$, de Vries $F$. Use of high-dose intermittent systemic glucocorticoids and the risk of fracture in patients with chronic obstructive pulmonary disease. Bone 2018; 110(07): 238-243.

6. Haberman $R H$, Castillo $R$, Chen $A$, Yan $D$, Ramirez $D$, Sekar $V$, Lesser R, Solomon G, Neimann AL, Blank RB, et al. NYU WARCOV Investigators. COVID-19 in Patients with Inflammatory Arthritis: A Prospective Study on the Effects of Comorbidities and Disease-Modifying Antirheumatic Drugs on Clinical Outcomes. Arthritis Rheumatol 2020; 72(12): 1981-1989.

Trop J Pharm Res, June 2021; 20(6): 1277 
7. Fardet L, Fève B. Systemic glucocorticoid therapy: a review of its metabolic and cardiovascular adverse events. Drugs 2014; 74(15): 1731-45.

8. Duffy SP, Criner GJ. Chronic Obstructive Pulmonary Disease: Evaluation and Management. Med Clin North Am 2019; 103(3): 453-461.

9. Negewo NA, Gibson PG, McDonald VM. COPD and its comorbidities: Impact, measurement and mechanisms. Respirology 2015; 20(8): 1160-71.

10. Segal LN, Martinez FJ. Chronic obstructive pulmonary disease subpopulations and phenotyping. J Allergy Clin Immunol 2018; 141(6): 1961-1971.

11. Poh TY, Mac Aogáin M, Chan AK, Yii AC, Yong VF, Tiew $P Y$, Koh MS, Chotirmall SH. Understanding COPDoverlap syndromes. Expert Rev Respir Med 2017; 11(4): 285-298.

12. Ritchie Al, Wedzicha JA. Definition, Causes, Pathogenesis, and Consequences of Chronic Obstructive Pulmonary Disease Exacerbations. Clin Chest Med 2020; 41(3): 421-438.

13. Gloeckl R, Marinov B, Pitta F. Practical recommendations for exercise training in patients with COPD. Eur Respir Rev 2013; 22(128): 178-86.
14. Smith MC, Wrobel JP. Epidemiology and clinical impact of major comorbidities in patients with COPD. Int $\mathrm{J}$ Chron Obstruct Pulmon Dis 2014; 9: 871-88.

15. Cassady SJ, Reed RM. Pulmonary Hypertension in COPD: A Case Study and Review of the Literature. Medicina (Kaunas) 2019; 55(8): 432

16. Grindrod K. Management of stable chronic obstructive pulmonary disease. Br J Community Nurs 2015; 20(2): 58, 60-4.

17. Agustí A, Vogelmeier C, Faner R. COPD 2020: changes and challenges. Am J Physiol Lung Cell Mol Physiol 2020; 319(5): L879-L883.

18. Polverino F, Celli B. The Challenge of Controlling the COPD Epidemic: Unmet Needs. Am J Med 2018; 131(9S): 1-6.

19. Chen $X, X u X$, Xiao F. Heterogeneity of chronic obstructive pulmonary disease: from phenotype to genotype. Front Med 2013; 7(4): 425-32.

20. Wiles SP, Aboussouan LS, Mireles-Cabodevila E. Noninvasive positive pressure ventilation in stable patients with COPD. Curr Opin Pulm Med 2020; 26(2): 175-185. 